\title{
Determinants of Corporate Social Responsibility Data Collection in Polish Enterprises
}

DOI: http://dx.doi.org/10.12775/JCRL.2017.020

\author{
JOLANTA MAJ \\ Opole University of Technology, Opole, Poland \\ e-mail: j.maj@po.opole.pl
}

\begin{abstract}
Purpose: Studies suggest that organisations tend to a selective disclosure of non-financial information. Researchers have analysed many determinants of corporate social responsibility disclosure. However relatively little attention has been devoted to the topic of the sustainability reporting process and how the reports are developed, which includes also the question of data collection and its determinants. The paper tries to determine whether selected variables: the size of the organisation, financial performance, operating on foreign markets, the issue of stakeholders mapping and preparing of non-financial reports influence the detail of collected non-financial information in Polish organisations.

Design/methodology/approach: For this purpose CATI research with 102 companies listed on the Warsaw stock exchange has been conducted. The obtained results have been analysed using V Cramer contingency measure and the Kruskal-Wallis $\mathrm{H}$ test.

Findings: The undertaken research shows there are statistically significant differences between the detail of non-financial information collected by organisations mapping and not-mapping stakeholders. In relation to the influence of the size of the organisation the obtained results were not statistically significant, yet showed a moderate correlation between those
\end{abstract}


variables. Similar results were obtained for the other variables. Statistically relevant correlation has been determined in regard to the influence of operating on foreign markets and the detail of the collected data regarding respect for human rights, financial performance and the detail of collected information regarding respect for human rights and anti-corruption and bribery matters and the correlation between the fact of preparing non-financial reports and the detail of the collected environmental information.

Research and practical limitations/implications: The limitations of the study result from the fact, that the questionnaire has been build using the Likert scale, for most of the questions, the quantitative nature of the presented answers imposed the choice of tools for the analysis of quantitative variables which allow for limited conclusions about the nature of the correlation.

Originality/value: Based on the analysis of the existing state of art and to the best knowledge of the author the issue of determinants of collecting CSR data has not been analysed yet. Thus, this paper tries to start a discussion regarding a previously neglected issue.

Paper type: research paper.

Keywords: corporate social responsibility, collecting non-financial information, collection CSR information, sustainability reporting.

\section{Introduction}

Corporate social responsibility (CSR) has a long history, dating back to the 1950s and undergoing since then many changes (Moura-Leite and Padgett, 2011). During this time CSR has been a subject of interest for decision makers, which resulted in the adoption of several declarations, documents and international laws (Hawrysz, 2017). One of the most active international actors has been the European Union, which recognised corporate social responsibility as an important issue of economic policy and started initiatives across Europe to legally regulate CSR issues (Skrzypek, 2015), which led i.e. to the adoption of the Directive 2014/95/EU, which obligates large public interest organisations meeting additional requirements regarding the number of employees, balance sheet total, and net turnover to disclose non-financial and diversity information. Organisations meeting those requirements are obliged to disclose the information as of 1 January 2017 (European Commission, 2014). However, as previous research shows, Polish organisations are 
not inclined to disclose non-financial information (Hawrysz, 2016a, 2016b). Furthermore studies indicate that where reporting requirements exists, they are unlikely to meet the requirements of the stakeholders (Williamson and Lynch-Wood, 2008) and where there are no formal, legal norms for promotion of CSR, limited actions are being undertaken (Garcia-Sanchez, Cuadrado-Ballesteros and Frias-Aceituno, 2016), which may indicate, that the coercive pressure (Martinez-Ferrero and Garcia-Sanchez, 2017) may not be the main determinant for CSR disclosure and for collecting non-financial information.

All entities affected by an organisation have the right to information regarding the consequences of its functioning. Reporting of non-financial data is being perceived as an important element of the dialogue with stakeholders (Gray, Kouhy and Lavers, 1995) and reflects the organisational strategy (Moneva, Rivera-Lirio and Munoz-Torres, 2007). Nevertheless organisations tend to disclose non-financial information in a selective way (Borys, 2015; Borys and Czaja, 2009; Kleinfeld and Martens, 2014; Kozlowski, Searcy and Bardecki, 2015). However conscious and mature management of corporate social responsibility, using and based on reliable reporting is the foundation for systemic CSR, CSR 2.0 (Visser, 2016) being a driver for innovation (Bębenek, 2015, 2016, 2017).

\section{Disclosing and collecting non-financial data}

As already indicated, studies suggest that organisations tend to a selective disclosure of non-financial information. Many researchers analysed the determinants of disclosing non-financial information (Ali, Frynas and Mahmood, 2017) and especially environmental information (Ortas, Gallego-Alvarez and Etxeberria, 2015). Among determinants, which influence the disclosure of non-financial information, researchers pointed to characteristics of the organisation i.e. size of the organisation (Bouten, Everaert, Van Liedekerke, De Moor and Christiaens, 2011; Dienes, Sassen and Fischer, 2016; Gallego-Alvarez, Rodriguez-Dominguez and Garcia-Sanchez, 2011), the companies' leverage (Ortas et al., 2015), performance (Khanna, Palepu and Srinivasan, 2004), operating of the organisation on foreign markets (Freedman and Jaggi, 2011), media visibility (Dienes et al., 2016), ownership structure (Dienes et al., 2016), research and development expenditures (Ortas et al., 2015), 
industry (Ali et al., 2017; Bouten et al., 2011; Brammer and Pavelin, 2008; Cormier, Magnan and Van Velthoven, 2005), age of assets (Cormier et al., 2005). Furthermore the influence of general contextual factors on CSR disclosure has been analysed, which has shown variation between CSR practices and especially CSR disclosure (Jackson and Apostolakou, 2010; Matten and Moon, 2008). Differences in the effects of the national institutional context has been found between the United States and Europe (Matten and Moon, 2008) but also between European countries (Knudsen, Moon and Slager, 2015). According to Ali et al. (2017) relatively little attention has been paid towards internal contextual factors. The so far undertaken studies have concentrated on corporate executives attitudes towards CSR disclosure (Adams, 2002).

However, the analysis of the state of art reveals an existing theoretical gap. Whereas researchers try to find the determinants of disclosure of non-financial information, the issue of determinants of collecting CSR data has, to the best knowledge of the author, not yet been analysed. While it is possible, and also has been undertaken in this paper, to draw conclusions from the determinants of disclosure onto the determinants of collecting non-financial data it has to be remembered and emphasised that the issue of why and what non-financial information organisations collect and what then is being disclosed may be two different things, as it has already been shown, that data collection does not ensure that managers will act ethically (Adams and Frost, 2008). Relatively little research has been devoted to the topic of the sustainability reporting process and how CSR reports are developed (Adams and Frost, 2008; Searcy and Buslovich, 2014). Furthermore, as noted by Searcy and Buslovich (2014), data collection is one of key challenges in developing sustainability reports. The issue of collecting non-financial information has been subject to analysis on measuring corporate social responsibility, the available methods (Turker, 2009) and tools (Melanie and Dina, 2014) but not determinants of the process.

In accordance with the established determinants of disclosure of non-financial information the paper tries to determine whether selected variables are also determinants of collecting non-financial data. For the purpose of this paper following variables have been chosen: the size of the organisation, financial performance, operating on foreign markets (which have been established as determinants of corporate social responsibility disclosure) and the issues of stakeholders mapping and preparing of non-financial reports. The main 
goal of the paper is to examine whether those variables influence the detail of collected non-financial information. In accordance with the mentioned Directive 2014/95/EU the non-financial information has been analysed with breakdown to environmental matters, social and employee-related matters, respect for human rights, anti-corruption and bribery matters and employee diversity, which are categories specified in the Directive.

\section{Methodology}

The study sample included 102 companies listed on the Warsaw stock exchange. The full population included 493 organisations that were invited to take part in the CATI (computer assisted telephone interview) research. The main reason for organisations declining the participation in the study was the fact that the organisations do not have a corporate social responsibility strategy implemented and therefore do not disclose any non-financial data. Some of the Respondents stated, that for the participation in the study they would need to obtain permission from the Board. The questionnaire has been developed based on the analysis of the existing literature, however the questions included in the research tool were results of an operationalisation conducted for the purpose of this research.

The research itself handled several questions regarding disclosure of non-financial and diversity information. Hence, this paper presents only a chosen part of the research. The questionnaire has been pre-tested during a pilot study conducted in July 2016. As a result of the pilot study minor corrections to the questionnaire have been introduced. The main study was conducted in the period from September to November 2016. The time of the study results from the Directive of the European Parliament and Council 2014/95/EU, which obliges large public interest organisations to disclose non-financial data starting from January 2017.

Due to the fact, that the questionnaire has been build using the Likert scale, for most of the questions, the quantitative nature of the presented answer choices imposed the choice of tools for the analysis of quantitative variables. Therefore, the $\mathrm{V}$ Cramer contingency measure and the Kruskal-Wallis $\mathrm{H}$ test have been used. Thus, due to the nature of the V Cramer contingency measure it was only possible to verify 
whether there is a relationship between the chosen variables and the detail of collected data without pointing to the direction of the discovered correlation.

\section{Results}

The first analysed issue was question of whether there are differences between the detail of non-financial information gathered between organisations mapping and not mapping stakeholders. For this purpose the Kruskal-Wallis $H$ test has been used. The results, in regard to the particular non-financial information category have been presented in Table 1 . The organisations were asked to assess the detail of the collected non-financial information in five areas on a scale from 1 to 5 where 1 meant that the organisations did not collect the data at all and 5 meant that the collected data was very detailed.

Table 1. Differences in the detail of collected CSR data in organisations mapping and not mapping stakeholders

\begin{tabular}{|c|c|c|c|c|}
\hline \multirow[b]{2}{*}{ Non-financial reporting areas } & \multirow[b]{2}{*}{$\mathbf{H}$} & \multirow[b]{2}{*}{ p- value } & \multicolumn{2}{|l|}{ Median } \\
\hline & & & $\begin{array}{l}\text { Organ- } \\
\text { isations } \\
\text { mapping } \\
\text { stakeholders }\end{array}$ & $\begin{array}{l}\text { Organisa- } \\
\text { tions not } \\
\text { mapping } \\
\text { stakeholders }\end{array}$ \\
\hline Environmental matters & 36,1054 & 0,0000 & 4 & 2 \\
\hline $\begin{array}{l}\text { Social and employee-related } \\
\text { matters }\end{array}$ & 15,6998 & 0,0001 & 4 & 4 \\
\hline Respect for human rights & 59,3477 & 0,0000 & 4 & 1 \\
\hline $\begin{array}{l}\text { Anti-corruption and bribery } \\
\text { matters }\end{array}$ & 58,8495 & 0,0000 & 4 & 1 \\
\hline Employee diversity & 66,0851 & 0,0000 & 4 & 1 \\
\hline
\end{tabular}

Source: Own research.

The presented data shows, that there are statistically significant differences between the detail of non-financial information collected by organisations mapping and not-mapping stakeholders. Organisations mapping stakeholders declared that they gather detailed information regarding all categories, whereas those not mapping stakeholders 
gather mostly information regarding social and employee-related matters (however not related to diversity). Therefore, it may be concluded, that the issue of stakeholder mapping may be the first determinant of the detail of collected non-financial data. Due to the fact that the organisations not mapping stakeholders collect almost no non-financial information, the further analysis has been conducted only on data gathered from organisations stating that they do map stakeholders.

The second analysed issue has been the question of whether the number of employees (size of the organisation) influences the detail of the collected data. The results have been presented in Table 2 .

Table 2. The dependence between the enterprises size and the detail of collected CSR data

\begin{tabular}{lcccc}
\hline Non-financial reporting areas & $\mathbf{X}$ & $\mathbf{d f}$ & $\mathbf{p}$-value & $\mathbf{V}$ \\
\hline Environmental matters & 11,9160 & 6 & 0,0639 & 0,4532 \\
\hline Social and employee-related matters & 4,1339 & 2 & 0,1266 & 0,3776 \\
\hline Respect for human rights & 5,2837 & 6 & 0,5080 & 0,3018 \\
\hline Anti-corruption and bribery matters & 4,8333 & 6 & 0,5654 & 0,2887 \\
\hline Employee diversity & 12,4458 & 8 & 0,1324 & 0,4632 \\
\hline
\end{tabular}

Source: Own research.

The obtained results are not statistically significant. Furthermore, it should be noticed that the values reached by the V Cramer coefficient give evidence of a weak to moderate correlation between the organisations size and the detail of the collected non-financial information. Therefore, it is not possible to determine a statistically relevant dependency between those two variables.

Next, the influence of the operating on foreign markets on the detail of collected non-financial information has been investigated. The results have been presented in Table 3 .

The obtained results, with the exception of respect for human rights, are not statistically significant. However, it is important to notice that the values reached by the V Cramer coefficient give evidence of a moderate correlation between the fact of operating on foreign markets and the detail of the collected non-financial information. Therefore, it is not possible to determine a statistically relevant dependency between those two variables with an exception of respect for human rights, where the 
Table 3. The dependence between operating on foreign markets and the detail of collected CSR data

\begin{tabular}{lcccc}
\hline Non-financial reporting areas & $\mathbf{x}$ & df & p-value & V \\
\hline Environmental matters & 3,7427 & 2 & 0,1540 & 0,3592 \\
\hline Social and employee-related matters & 3,7427 & 2 & 0,1540 & 0,3592 \\
\hline Respect for human rights & 7,1145 & 2 & 0,0285 & 0,4953 \\
\hline Anti-corruption and bribery matters & 6,8254 & 4 & 0,1454 & 0,4937 \\
\hline Employee diversity & 4,0353 & 3 & 0,2577 & 0,3730 \\
\hline
\end{tabular}

Source: Own research.

data shows a moderate, but statistically significant, correlation between the analysed variables.

The next analysed issue was the relation between the declared financial performance and the detail of collected non-financial data. The results have been presented in Table 4 .

Table 4. The dependence between the organisations financial performance and the detail of collected CSR data

\begin{tabular}{lcccc}
\hline Non-financial reporting areas & $\mathbf{x}$ & df & p-value & V \\
\hline Environmental matters & 5,7935 & 6 & 0,4467 & 0,3161 \\
\hline Social and employee-related matters & 3,0996 & 2 & 0,2123 & 0,3269 \\
\hline Respect for human rights & 13,1946 & 6 & 0,0401 & 0,4770 \\
\hline Anti-corruption and bribery matters & 13,4072 & 6 & 0,0370 & 0,4808 \\
\hline Employee diversity & 13,6361 & 8 & 0,0918 & 0,4849 \\
\hline
\end{tabular}

Source: Own research.

The obtained results, with the exception of respect for human rights and anti-corruption and bribery matters are not statistically significant. However, it should be notice that the values reached by the V Cramer coefficient give evidence of a moderate correlation between the organisations declared financial performance and the detail of the collected non-financial information. It is not possible to determine a statistically relevant dependency between those two variables, with the exception of the influence of the organisations declared financial performance and 
the issues of respect for human rights as well as anti-corruption and bribery matters.

Next, the influence of preparing non-financial reports on the detail of collected non-financial information has been investigated. The results have been presented in Table 5 .

Table 5. The dependence between preparing non-financial reports and the detail of collected CSR data

\begin{tabular}{lcccc}
\hline Non-financial reporting areas & $\mathbf{x}$ & df & p- value & V \\
\hline Environmental matters & 9,1162 & 3 & 0,0278 & 0,5607 \\
\hline Social and employee-related matters & 3,4801 & 1 & 0,0621 & 0,2446 \\
\hline Respect for human rights & 5,9974 & 3 & 0,1117 & 0,4548 \\
\hline Anti-corruption and bribery matters & 5,8816 & 3 & 0,1175 & 0,4503 \\
\hline Employee diversity & 6,3974 & 4 & 0,1714 & 0,4697 \\
\hline
\end{tabular}

Source: Own research.

The obtained results, with the exception of environmental data, are also not statistically significant. However, it is important to notice that the values reached by the V Cramer coefficient give evidence of a moderate correlation between the fact of preparing non-financial reports and the detail of the collected non-financial information. Therefore, it is not possible to determine a statistically relevant dependency between those two variables, with the exception of the influence of preparing non-financial reports on the detail of collected environmental data, where a statistically relevant and relatively high influence has been identified.

\section{Conclusion}

The main purpose of this paper was to verify whether selected variables: the size of the organisation, financial performance, operating on foreign markets (which have been established as determinants of corporate social responsibility disclosure) and the issues of stakeholders mapping and preparing of non-financial reports influence the detail of disclosed non-financial information. The conducted research and analysis have shown a moderate correlation between those variables. In regard to the issue of stakeholder mapping the research has shown 
statistically significant differences between the detail of non-financial information collected by organisations mapping and not-mapping stakeholders. Statistically relevant correlation has also been determined in regards to the influence of operating on foreign markets as well as the organisations financial performance and the detail of the collected data regarding respect for human rights, financial performance and the detail of collected information regarding anti-corruption and bribery matters and the correlation between the fact of preparing non-financial reports and the detail of the collected environmental information. However, due to the diagnosed moderate level correlation, the issue requires further analysis and deepening. Also, due to the fact the only companies listed on the Warsaw Stock Exchange have been taken into consideration the results cannot be treated as representative for all Polish organisations.

The presented results have practical implications, as in some cases a moderate correlation has been detected. The results show that the chosen organisational characteristics do not determine the detail of collected non-financial information and therefore do not close the door of reporting for smaller organisations, operating locally with weaker financial performance. The results also show, that mapping stakeholders may have influence on the detail of collected non-financial information as organisations mapping stakeholders generally collect more detailed data.

As already indicated relatively little attention has been devoted to the topic of the sustainability reporting process and how the reports are developed, which includes also the question of data collection and its determinants. This paper tries to start a discussion regarding a previously neglected issue. It shows, that while most of the analysed variables influence the disclosure of non-financial information it is not necessarily the same when it comes to collecting non-financial data. Adams and Frost (2008) determined that data collection does not ensure that managers will act ethically. It is therefore also possible that data collection does not ensure that all the information collected is also disclosed. This is an issue, which requires further investigation. The conducted analysis shows that also the determinants and motives for collecting and disclosing non-financial information may be different, therefore making the need for an analysis of determinants of collecting non-financial data so much more necessary. 


\section{References}

Adams, C.A. (2002), "Internal Organisational Factors Influencing Corporate Social and Ethical Reporting: Beyond Current Theorising”, Accounting, Auditing \& Accountability Journal, Vol. 15, Issue 2, pp. 223-250.

Adams, C.A., Frost, G.R. (2008) "Integrating Sustainability Reporting into Management Practices”, Accounting Forum, Vol. 32, Issue 4, pp. 288-302.

Ali, W., Frynas, J.G., Mahmood, Z. (2017), “Determinants of Corporate Social Responsibility (CSR) Disclosure in Developed and Developing Countries: A Literature Review", Corporate Social Responsibility and Environmental Management, Vol. 24, Issue 4, pp. 273-294.

Borys, T. (2015), “Zrównoważony rozwój organizacji - co chcemy lub powinniśmy równoważyć?”, Prace Naukowe Uniwersytetu Ekonomicznego we Wrocławiu, No. 376, pp. 13-24.

Borys, T., Czaja, S. (2009), "Badania nad zrównoważonym rozwojem w polskich ośrodkach naukowych”, in Kiełczewski, D. (Ed.), Od koncepcji ekorozwoju do ekonomii zrównoważonego rozwoju, Wydawnictwo Wyższej Szkoły Ekonomicznej, Białystok, pp. 51-75.

Bouten, L., Everaert, P., Van Liedekerke, L., De Moor, L., Christiaens, J. (2011), “Corporate Social Responsibility Reporting: A Comprehensive Picture?”, Accounting Forum, Vol. 35, Issue 3, pp. 187-204.

Brammer, S., Pavelin, S. (2008), "Factors Influencing the Quality of Corporate Environmental Disclosure”, Business Strategy and the Environment, Vol. 17, Issue 2, pp. $120-136$.

Bębenek, P. (2015), “Enterprise Innovation Management - Integration of the Process, Product, Marketing and Organization Changes”, in: Malik K., Dymek Ł., (Eds.), Effective Transfer of Knowledge from Science to Industry in the Opolskie Voivodeship. Requirements for Effective Cooperation, Difin, Warszawa, pp. 165-175,

Bębenek, P. (2016), "Project and Innovation Management in Agriculture - Outsourcing and Protection of the Environment in Polish Farms", in: Ecology, Economics, Education and Legislation Conference Proceedings, SGEM 2016, Stef92 Technology Ltd., Sofia.

Bębenek, P. (2017), "Effective Innovation Management in a Company - Innovation Assessment Criteria”, Proceedings of the $4^{\text {th }}$ International Multidisciplinary Scientific Conferences SGEM2017, Social Sciences \& Art, Albena, Bulgaria, Stef92 Technology Ltd., Sofia.

Cormier, D., Magnan, M., Van Velthoven, B. (2005), “Environmental Disclosure Quality in Large German Companies: Economic Incentives, Public Pressures or Institutional Conditions?”, European Accounting Review, Vol. 14, Issue 1, pp. 3-39.

Dienes, D., Sassen, R., Fischer, J. (2016), "What Are the Drivers of Sustainability Reporting? A Systematic Review”, Sustainability Accounting Management and Policy Journal, Vol. 7, Issue 2, pp. 154-189.

European Commission (2014), Directive 2014/95/EU of the European Parliament and the Council of 22 October 2014 amending Directive 2013/34/EU as Regards DisClosure of Non-financial and Diversity Information by Certain Large Undertakings and Groups. ABIEU L, 330, 1-9. 
Freedman, M., Jaggi, B. (2011), “Global Warming Disclosures: Impact of Kyoto Protocol Across Countries”, Journal of International Financial Management \& Accounting, Vol. 22, Issue 1, pp. 46-90.

Gallego-Alvarez, I., Rodriguez-Dominguez, L., Garcia-Sanchez, I.M. (2011), "Study of Some Explanatory Factors in the Opportunities Arising from Climate Change”, Journal of Cleaner Production, Vol. 19, Issue 9-10, pp. 912-926.

Garcia-Sanchez, I.M., Cuadrado-Ballesteros, B., Frias-Aceituno, J.V. (2016), “Impact of the Institutional Macro Context on the Voluntary Disclosure of CSR Information”, Long Range Planning, Vol. 49, Issue 1, pp. 15-35.

Gray, R., Kouhy, R., Lavers, S. (1995), “Corporate Social and Environmental Reporting: A Review of the Literature and a Longitudinal Study of UK Disclosure”, Accounting, Auditing \& Accountability Journal, Vol. 8, Issue 2, pp. 47-77.

Hawrysz, L. (2016a), "Environmental Aspects of CSR Reporting in Polish Chemistry Sector Enterprices Listed on the Warsaw Stock Exchange”, in: Ecology, Economics, Education and Legislation Conference Proceedings, SGEM 2016, Stef92 Technology Ltd., Sofia.

Hawrysz, L. (2016b), "Social Aspects of CSR Reporting in Polish Banks Listed on the Warsaw Stock Exchange”, in Conference Proceedings of the $3^{\text {rd }}$ International Multidisciplinary Conference SGEM 2016, Stef92 Technology Ltd., Sofia, pp. 587-594.

Hawrysz, L. (2017), "Przygtowanie spółek giełdowych do ujawniania informacji pozafinansowych”, Prace Naukowe Uniwersytetu Ekonomicznego we Wrocławiu, No. 470, pp. 40-51.

Jackson, G., Apostolakou, A. (2010), “Corporate Social Responsibility in Western Europe: An Institutional Mirror or Substitute?”, Journal of Business Ethics, Vol. 94, Issue 3, pp. 371-394.

Khanna, T., Palepu, K.G., Srinivasan, S. (2004), "Disclosure Practices of Foreign Companies Interacting with US Markets”, Journal of Accounting Research, Vol. 42, Issue 2, pp. 475-508.

Kleinfeld, A., Martens, A. (2014), “Transparenz: Berichterstattung über Nachhaltigkeitsleistungen”, in: Schulz T., Bergius S., (Eds.), CSR und Finance: Beitrag und Rolle des CFO für eine Nachhaltige Unternehmensführung, Springer, Berlin, Heidelberg, pp. 219-235.

Knudsen, J.S., Moon, J., Slager, R. (2015), “Government Policies for Corporate Social Responsibility in Europe: A Comparative Analysis of Institutionalisation”, Policy and Politics, Vol. 43, Issue 1, pp. 81-99.

Kozlowski, A., Searcy, C., Bardecki, M. (2015), "Corporate Sustainability Reporting in the Apparel Industry: An Analysis of Indicators Disclosed”, International Journal of Productivity and Performance Management, Vol. 64, Issue 3, pp. 377-397.

Martinez-Ferrero, J., Garcia-Sanchez, I.M. (2017), “Coercive, Normative and Mimetic Isomorphism as Determinants of the Voluntary Assurance of Sustainability Reports”, International Business Review, Vol. 26, Issue 1, pp. 102-118.

Matten, D., Moon, J. (2008), “»Implicit« and »Explicit« CSR: A Conceptual Framework for a Comparative Understanding of Corporate Social Responsibility”, Academy of Management Review, Vol. 33, Issue 2, pp. 404-424.

Melanie, B.L., Dina, K. (2014), The Changing Landscape of Corporate Social Responsibility Reporting. Paper presented at the Society of Petroleum Engineers - SPE 
International Conference on Health, Safety and Environment 2014: The Journey Continues.

Moneva, J.M., Rivera-Lirio, J.M., Munoz-Torres, M.J. (2007), “The Corporate Stakeholder Commitment and Social and Financial Performance”, Industrial Management \& Data Systems, Vol. 107, Issue 1-2, pp. 84-102.

Moura-Leite, R.C., Padgett, R.C. (2011), "Historical Background of Corporate Social Responsibility”, Social Responsibility Journal, Vol. 7, Issue 4, pp. 528-539.

Ortas, E., Gallego-Alvarez, I., Etxeberria, I.A. (2015), “Financial Factors Influencing the Quality of Corporate Social Responsibility and Environmental Management Disclosure: A Quantile Regression Approach”, Corporate Social Responsibility and Environmental Management, Vol. 22, Issue 6, pp. 362-380.

Searcy, C., Buslovich, R. (2014), “Corporate Perspectives on the Development and Use of Sustainability Reports”, Journal of Business Ethics, Vol. 121, Issue 2, pp. 149-169.

Skrzypek, E. (2015), “Społeczna odpowiedzialność - standardy i raportowanie”, Prace Naukowe Uniwersytetu Ekonomicznego we Wroclawiu, No. 378, pp. 206-217.

Turker, D. (2009), "Measuring Corporate Social Responsibility: A Scale Development Study”, Journal of Business Ethics, Vol. 85, Issue 4, pp. 411-427.

Visser, W. (2016), “The Future of CSR: Towards Transformative CSR, or CSR 2.0.”, Research Handbook on Corporate Social Responsibility in Context, pp. 339-367.

Williamson, D., Lynch-Wood, G. (2008), "Social and Environmental Reporting in UK Company Law and the Issue of Legitimacy”, Corporate Governance, Vol. 8, Issue 2, pp. 128-140. 
